\title{
JM
}

Volume 7 No. 2 (Oktober 2019)

(C) The Author(s)

\section{HUBUNGAN PENGETAHUAN, SUMBER INFORMASI DAN PERAN NAKES TERHADAP PERILAKU PENCEGAHAN SKABIESDI PESANTREN PANCASILA KOTA BENGKULU}

\section{RELATIONS KNOWLEDGE, A SOURCE OF INFORMATION AND THE ROLE OF HEALTH WORKERS TO BEHAVIOR PREVENTION SCABIES IN BOARDING PANCASILA BENGKULU}

\author{
TAUFIANIE ROSSITA \\ PROGRAM STUDI KEBIDANAN (S1) FAKULTAS ILMU KESEHATAN \\ UNIVERSITAS DEHASEN BENGKULU \\ Email : taufianirossita255@gmail.com
}

\begin{abstract}
ABSTRAK
Masalah kesehatan yang sering dialami masyarakat indonesia adalah masalah penyakit kulit yaitu skabies/ kudis yang sering dijumpai ditempat yang padat penduduk, penyakit ini sering muncul di pondok pesantren yang padat penghuninya, karena pencegahan penyakit skabies bergantung dengan perilaku hidup seseorang yang kurang baik. Tujuan penelitian ini adalah mengetahui hubungan pengetahuan, sumber informasi dan peran tenaga kesehatan terhadap perilaku pencegahan penyakit skabies di pesantren Pancasila. Penelitian ini menggunakan metode deskriptif analitik dengan menggunakan pendekatan cross sectional. Sampel dalam penelitian berjumlah 76 responden. Teknik pengambilan sampel menggunakan Total Sampling. Hasil menunjukkan 59,2\% perilaku pencegahan skabies kurang baik. Hasil uji statistik chi square dengan tingkat kemaknaan $\alpha=0,05$. Hasil analisis bivariat didapatkan Pengetahuan $(\mathrm{OR}=3,782 ; \rho$ value $=0,012)$, Sumber Informasi $(\mathrm{OR}=8,886 ; \rho$ value $=0,000)$, Peran Tenaga Kesehatan $(\mathrm{OR}=5,775 ; \rho$ value $=0,001)$. Maka dapat disimpulkan ada hubungan antara pengetahuan, sumber informasi dan peran tenaga kesehatan terhadap perilaku pencegahan skabies, dari penelitian ini diharapkan semua pihak baik petugas kesehatan maupun pihak pesantren dapat memperbaharui serta melakukan pembinaan secara rutin kepada para santri dalam upaya menjaga kebersihan diri dan lingkungan agar dapat mencegah penyakit skabies.
\end{abstract}

\section{Kata Kunci : Pengetahuan, Sumber Informasi dan Peran Tenaga Kesehatan}

\begin{abstract}
Health problems that often experienced indonesians is a problem skin diseases such as scabies/ scab which often found in densely populated, disease it appears often in a hut pesantren solid its inhabitants, because the prevention of disease skabies to depend behavior life for the person a less well.The purpose of this research is to know relations knowledge, a source of information and role of health workers to behavior the prevention of disease scabies in boarding Pancasila. This research uses the method descriptive analytic by adopting cross sectional.Sample in research were 76 respondents. Technique the sample collection use total of sampling. Results showing 59,2\% behavior prevention scabies less well. The results of statistical tests chi square
\end{abstract}


with yield significant level $\alpha=0,05$. The results of the analysis bivariat obtained knowledge $(\mathrm{OR}=3,782 ; \rho$ value $=0,012)$, a source of information $(\mathrm{OR}=8,886 ; \rho$ value $=0,000)$, the role of health workers $(\mathrm{OR}=5,775 ; \rho$ value $=0,001)$. So can be concluded there was a correlation between knowledge, a source of information and role of health workers to behavior scabies prevention, of research is expected all parties right officer health or the boarding can renew and provide guidance routinely to the students in this effort to ensure cleanliness themselves and the environmental from can prevent the disease scabies.

\section{Keywords : Knowledge , A source of information and Role of health workers}

\section{PENDAHULUAN}

Kesehatan adalah keadaan sejahtera dari badan, jiwa dan sosial yang membuat seseorang bisa hidup produktif secara sosial dan ekonomi. Kesehatan juga menjadi kunci utama kita bisa beraktivitas secara normal dan rutin. Masalah kesehatan merupakan masalah yang sangat kompleks, banyak faktor yang mempengaruhi kesehatan, diantaranya adalah peran tenaga kesehatan dan pengetahuan masyarakat dalam merespon suatu penyakit (Notoatmodjo, 2010)

Salah satu masalah kesehatan yang banyak dialami oleh sebagian besar masyarakat di Indonesia adalah masalah kesehatan yang menyerang sistem perlindungan tubuh paling luar, yaitu kulit. Kulit adalah organ tubuh yang terletak paling luar dan membatasinya dari lingkungan hidup manusia dan organ yang ensensial dari vital serta merupakan cermin kesehatan dan kehidupan. Kulit juga sangat sensitiv bergantung pada lokasi tubuh (Harahap, 2018).

Penyakit kulit bisa disebabkan oleh banyak faktor, diantaranya faktor lingkungan dan kebiasaan hidup sehari-hari. Lingkungan yang sehat dan bersih akan membawa efek yang baik pula bagi kulit. Demikian juga sebaliknya, lingkungan yang kotor akan menjadi sumber munculnya berbagai macam penyakit, selain itu kulit juga mempunyai nilai estetika. Penyakit kulit dapat disebabkan oleh jamur, virus, kuman, parasit hewani dan lain-lain. Salah satu penyakit kulit yang disebabkan oleh parasit adalah skabies (Djuanda, 2010)

Berdasarkan data WHO tahun 2009 penyakit ini telah ditemukan hampir pada semua Negara diseluruh dunia dengan angka prevalensi yang bervariasi. Prevalensi skabies di seluruh dunia dilaporkan sekitar 300 juta kasus per tahun. Berdasarkan data WHO tahun 2009 penyakit ini telah ditemukan hampir pada semua Negara diseluruh dunia dengan angka prevalensi yang bervariasi. Prevalensi skabies di seluruh dunia dilaporkan sekitar 300 juta kasus per tahun. (Haeri., 2013)

Indonesia sendiri tahun 2011 jumlah penderita skabies sebesar 2,9\% dari jumlah penduduk 238.452.952 jiwa. Jumlah ini meningkat pada tahun 2012 yang jumlah penderita skabies sebesar 3,6\% dari jumlah penduduk, sedangkan di Provinsi Bengkulu berdasarkan data dinas kesehatan tahun 2011, jumlah kasus baru penyakit skabies berjumlah 1135 orang, sedangkan tahun 2012 mengalami peningkatan lebih dari 2 kali lipat yaitu dari 1135 orang menjadi 2941 orang (Dinkes Prov. Bengkulu (2018)

Skabies dalam bahasa Indonesia sering disebut kudis. Orang jawa menyebutnya gudig, sedangkan orang sunda menyebutnya budug. Skabies merupakan penyakit menular akibat mikroorganisme parasit yang disebut Sarcoptes scabies varian humoris, yang ditandai dengan keluhan gatal terutama pada malam hari dan penularannya terjadi secara kontak langsung dan tidak langsung. Apabila skabies tidak segera mendapat pengobatan dalam beberapa minggu maka akan menimbulkan luka terbuka yang rentan terhadap infeksi yang diakibatkan karena garukan (Maharani, 2015).

Penyakit skabies ini mudah menyebar atau menular dari orang ke orang, terutama 
pada mereka yang tinggal di satu tempat yang padat penduduk seperti pesantren. hal ini dipengaruhi oleh perilaku kesehatan santri itu sendiri, perilaku hidup bersih dan sehat dengan cara mencuci pakaian dengan air bersih, mencuci handuk dengan air bersih, tidak tidur berdesakan, mandi teratur minimal $2 \mathrm{x}$ sehari, mencuci tangan dengan sabun, tidak memakai handuk secara bergantian, tidak tukar menukar pakaian dengan orang lain, menjemur kasur secara teratur, menjaga daya tahan tubuh, menjaga kebersihan tangan, kaki, kuku dan rambut dapat mempengaruhi pencegahan terhadap penyakit skabies. ( Badri, M.2015)

Para santri yang sering terkena penyakit skabies ini adalah santri baru yang belum dapat beradaptasi dengan lingkungan, sebagai santri baru yang belum tahu kehidupan di pondok pesantren membuat mereka luput dari kesehatan, yaitu mandi secara bersama-sama dan kurang bersih. Salah satu upaya dalam menanggulangi penyebaran penyakit skabies adalah dengan cara memberikan pendidikan kesehatan tentang penyakit ini (Notoadmodjo, 2007)

Pendidikan kesehatan adalah suatu kegiatan atau usaha untuk menyampaikan pesan tentang kesehatan kepada masyarakat kelompok atau individu. Sumber informasi juga menjadi peluang seseorang untuk meningkatkan pengetahuan. Tidak hanya peluang, penyebaran informasi yang semakin canggih akan mempermudah seseorang untuk mengetahui, memperbaiki dan meningkatkan pengetahuan mereka mengenai kesehatannya. Perilaku hidup sehat juga dipengaruhi oleh peran tenaga kesehatan, karena petugas kesehatan mempunyai peranan penting dalam pencegahan dan pengendalian masalah kesehatan di masyarakat, salah satu perannya yaitu memberikan penyuluhan kesehatan mengenai perilaku hidup bersih dan sehat seperti mandi 2 kali sehari. Keterpaparan pada penyuluhan kesehatan yang efektif sangat penting dalam meningkatkan sikap dan perilaku yang positif untuk mencegah suatu penyakit.

Berdasarkan penelitian Setyowati tahun
2014 didapatkan hasil santriwati memiliki pengetahuan yang baik sebanyak 155 (74,5\%) yang didukung dengan perilaku pencegahan terhadap penyakit skabies yang baik pula yaitu ada sebanyak $167(80,3 \%)$, sehingga terdapat hubungan antara pengetahuan para santriwati dengan perilaku pencegahan penyakit skabies di Pondok Pesantren Al Muayyad Surakarta

Berdasarkan penelitian Hidayat tahun 2011 didapatkan hasil responden yang mengikuti penyuluhan yang dilaksanakan oleh tenaga kesehatan memiliki kecenderungan berperilaku bersih dan sehat, dengan nilai OR sebesar 1,300 berarti bahwa responden yang mengikuti penyuluhan memiliki perilaku hidup bersih dan sehat

Berdasarkan latar belakang diatas dapat disimpulkan bahwa pengetahuan, sumber informasi dan peran tenaga kesehatan mempengaruhi terjadinya penyakit skabies, terutama pada santri baru yang belum dapat beradaptasi dengan lingkungan dan kehidupan di pondok pesantren, oleh karena itu peneliti ingin mengetahui hubungan pengetahuan, sumber informasi dan peran tenaga kesehatan terhadap perilaku pencegahan skabies pada santri kelas I di pesantren Pancasila Kota Bengkulu.

\section{METODE PENELITIAN}

Penelitian ini termasuk dalam penelitian kuantitatif dengan penelitian deskriptif analitik dengan menggunakan desain cross sectional yaitu suatu penelitian pada beberapa populasi yang diamati dalam waktu yang bersamaan pengukuran terhadap variabel independen (pengetahuan, sumber informasi dan peran tenaga kesehatan) dan untuk variabel dependen (perilaku pencegahan skabies) dan kemudian pengukuran terhadap variabel dependent serta independent dapat dilakukan dalam waktu bersamaan sehingga cukup efektif dan cukup efisien (Notoatmodjo, 2010)

Instrumen adalah alat yang digunakan dalam penelitian ini, untuk memperoleh data dalam penelitian menggunakan alat untuk 
mengumpulkan data menggunakan kuesioner terstruktur dengan pertanyaan tertutup yaitu pertanyaan yang kemungkinan jawabannya sudah ditentukan terlebih dahulu dan responden juga tidak diberi kesempatan untuk memberikan jawaban lain. Tujuan mengadakan kuesioner ini adalah untuk memperoleh informasi yang relevan. Instrumen dalam penelitian ini dengan mengumpulkan data berupa kuesioner. Semua aspek diambil secara bersamaan pada satu waktu sehingga tidak dapat menunjukkan hubungan sebab akibat secara pasti dan hanya menunjukkan keterkaitannya saja. Dalam penelitian ini yang ingin diketahui adalah mengenai hubungan pengetahuan, sumber informasi dan peran tenaga kesehatan pada para santri kelas I terhadap perilaku pencegahan skabies.

Peneliti mengumpulkan data dengan cara menggunakan data sekunder yang didapat di pesantren Pancasila Kota Bengkulu dan sebelum melakukan penelitian, terlebih dahulu peneliti mengamati gambaran area pesantren dan pencarian data-data lain yang relevan yang mendukung untuk penelitian ini, agar dapat mempermudah dan mempercepat penelitian.

Populasi adalah keseluruhan objek atau subjek yang berada pada suatu wilayah dan memenuhi syarat-syarat tertentu berkaitan dengan masalah penelitian, atau keseluruhan unit, individu dalam ruang lingkup yang akan diteliti. Populasi yang digunakan dalam penelitian ini adalah seluruh santri kelas I di Pesantren Pancasila Kota Bengkulu yang berjumlah 76 santri. Sampel adalah sebagian dari anggota populasi yang diambil menurut prosedur tertentu sehingga dapat mewakili populasinya, untuk sampel dalam penelitian ini adalah keseluruhan populasi santri yang ada berjumlah 76 santri. Teknik pengambilan sampel pada penelitian ini adalah total sampling.

\section{HASIL PENELITIAN}

Pada penelitian ini menggunakan analisis univariat dan bivariat, dalam analisis univariat data yang telah dipeoleh dari hasil pengumpulan data disajikan dalam bentuk tabel distribusi frekuensi dan teks. Analisis ini juga digunakan untuk menyederhanakan atau meringkas kumpulan data hasil pengukuran sehingga kumpulan data tersebut menjadi informasi yang berguna, sedangkan data univariat dalam penelitian ini akan terdiri dari variabel pengetahuan, sumber informasi dan peran tenaga kesehatan terhadap perilaku pencegahan skabies.

Data Univariat dalam penelitian ini terdiri dari pengetahuan, sumber informasi, dan peran tenaga kesehatan. Pada penelitian ini, terdapat penelitian yang akan di kelompokan meliputi variabel dependen kejadian skabies.

Hasil analisi bivariat ini menjelaskan secara statistik mengenai variabel penelitian pengetahuan, sumber informasi, peran tenaga kesehatan dan perilaku pencegahan skabies di pesantren. Hasil analisis bivariat ini menjelaskan secara statistik mengenai variabel penelitian yaitu variabel independen (pengetahuan, sumber informasi dan peran tenaga kesehatan) dan variabel dependennya (perilaku pencegahan skabies) untuk mengetahui adanya hubungan pengetahuan, sumber informasi dan peran tenaga kesehatan terhadap perilaku pencegahan skabies di Pesantren Pancasila Kota Bengkulu.

Dari hasil penelitian yang diperoleh dari hasil pengumpulan data terhadap 76 santri kelas satu di pesantren Pancasila Kota Bengkulu yang dilakukan pada bulan Mei sampai Juni. Penyajian data dalam penelitian ini meliputi variabel indepeden yaitu pengetahuan, sumber informasi dan peran tenaga kesehatan, serta variabel independennya perilaku pencegahan skabies. Jumlah sampel dalam penelitian ini adalah seluruh santri kelas satu yang sedang menempuh pendidikan dan bertempat tinggal di asrama pesantren Pancasila Kota Bengkulu yang berjumlah 76 santri dan tidak ada data yang hilang (missing).

Berdasarkan dari hasil penelitian ini, responden yang memiliki perilaku pencegahan skabies. Distribusi frekuensinya 
yaitu dalam penelitian ini bahwa perilaku pencegahan skabies kurang, memiliki nilai yang lebih besar dibandingkan dengan distribusi frekuensi perilaku pencegahan skabies yang baik, sedangkan distribusi frekuensi yang memiliki pengetahuan kurang dan tinggi menunjukkan bahwa pengetahuan kurang memiliki nilai lebih besar dibandingkan dengan pengetahuan baik. Distribusi frekuensi untuk sumber informasi kurang dan sumber informasi baik, menunjukkan bahwa sumber informasi kurang memiliki nilai lebih besar dibandingkkan dengan sumber informasi yang baik, begitu juga dengan distribusi frekuensi peran tenaga kesehatan yang kurang dan peran tenaga kesehatan yang baik, menunjukkan bahwa peran tenaga kesehatan yang kurang memiliki nilai yang lebih besar dibandingkan dengan peran tenaga kesehatan yang baik.

Penyajian data dalam penelitian ini meliputi variabel dependen dan independen yaitu: pengetahuan, sumber informasi dan peran tenaga kesehatan terhadap perilaku pencegahan skabies. Jumlah sampel sebanyak 76 santri, dan pada penelitian ini, terdapat penelitian yang akan di kelompokan menjadi 4 (empat) variabel yang meliputi variabel dependen perilaku pencegahan skabies $(\mathrm{Y})$, variabel independen pengetahuan $(\mathrm{X})$, sumber informasi (X) dan peran tenaga kesehatan $(\mathrm{X})$. berikut ini tabel hasil univariat dan bivariat dijelaskan dan dijabarkan dibawah ini:

Tabel 1 Distribusi Frekuensi Pengetahuan, Sumber Informasi Dan Peran Nakes Terhadap

\section{Perilaku Pencegahan Skabies}

\begin{tabular}{ccc}
\hline Variabel & Frekuensi (f) Presentase (\%) \\
\hline $\begin{array}{c}\text { Perilaku } \\
\text { Kurang }\end{array}$ & 45 & 59,2 \\
\hline Baik & 31 & 40,8 \\
\hline $\begin{array}{c}\text { Pengetahuan } \\
\text { Kurang }\end{array}$ & 46 & 60,5 \\
\hline Baik & 30 & 39,5 \\
\hline $\begin{array}{c}\text { Sumber Informasi } \\
\text { Rendah }\end{array}$ & 42 & 55,3 \\
\hline
\end{tabular}

\begin{tabular}{ccc}
\hline Tidak & 34 & 44,7 \\
\hline Peran Nakes & & \\
\hline Kurang & 43 & 56,6 \\
\hline Baik & 33 & 43,4 \\
\hline
\end{tabular}

Sumber : Hasil Olahan Data Komputerisasi 2015

Dari tabel 1 diatas dengan distribusi frekuensi pengetahuan, sumber informasi, peran tenaga kesehatan, perilaku pencegahan santri dapat dijelaskan dibawah ini: diketahui bahwa dari 76 responden, perilaku pencegahan skabies dibagi menjadi dua kategori yaitu perilaku pencegahan skabies kurang baik dan perilaku pencegahan skabies baik, dengan hasil perilaku pencegahan skabies kurang sebanyak 45 santri dengan persentase $59,2 \%$ dan sisanya 31 santri lain memiliki perilaku pencegahan skabies yang baik dengan persentase $40,8 \%$. Pengetahuan dibagi menjadi dua kategori yaitu pengetahuan kurang baik dan pengetahuan baik, dengan hasil santri yang memiliki pengetahuan kurang sebanyak 46 santri dengan persentase $60,5 \%$, sisanya 30 santri memiliki pengetahuan kurang dengan persentase 39,5\%. Sumber informasi juga terbagi menjadi dua kategori yaitu sumber informasi kurang baik dan baik, hasil yang didapat 42 santri dengan persentse 55,3\% yang memiliki sumber informasi kurang dan sisanya 34 santri dengan persentase $44,7 \%$ memiliki sumber informasi baik, untuk variabel peran nakes dibagi juga menjadi dua kategori yaitu peran nakes yang kurang baik dan baik, didapatkan hasil 43 santri dengan persentase $56,6 \%$ mengatakan peran nakes kurang baik dan sisanya 33 santri dengan persentase $43,4 \%$ mengatakan peran nakes berperan baik.

\section{PEMBAHASAN}

Penelitian ini menggunakan metode deskriptif analitik dengan cara pendekatan secara cross sectional (potong silang) yaitu pengukuran terhadap variabel independen (pengetahuan, sumber informasi dan peran tenaga kesehatan) dan variabel dependen 
(perilaku pencegahan skabies) dilakukan dalam waktu yang bersamaan dan dilakukan secara stimultan pada satu saat atau sesekali waktu.

Penelitian ini menggunakan data primer yang diperoleh dari penyebaran kuesioner pada para santri kelas satu yang menempuh pendidikan dan bertempat tinggal di pesantren Pancasila Kota Bengkulu. Penelitian ini tidak terlepas dari keterbatasan, diantaranya keterbatasan pengetahuan yang dimiliki oleh penulis, waktu penelitian yang dilakukan peneliti sangat singkat dan lain-lainnya. Alat ukur yang digunakan adalah kuesioner yang bersifat objektif karena kebenaran data dari hasil kuesioner sangat bergantung pada kejujuran responden dalam menjawab dan waktu yang terbatas di dalam penyebaran kuesioner, dikarenakan jadwal penyebaran kuesioner hanya dilakukan dalam sehari sehingga peniliti tidak maksimal dalam melakukan peniliti.

\section{Perilaku Pencegahan Skabies}

Perilaku Pencegahan skabies dapat di ukur dengan menggunakan alat ukur kuesioner yaitu menjawab pertanyaan sebanyak 15 pertanyaan. Hasil keseluruhan kuesioner di akumulasikan dan dibagikan dengan jumlah responden sehingga di dapatkan nilai rata- ratanya. Dari hasil penelitian didapatkan bahwa 45 santri $(59,2 \%)$ memiliki perilaku pencegahan skabies yang kurang baik dan 31 santri $(40,8 \%)$ memiliki perilaku pencegahan skabies baik

Penelitian ini sesuai dengan penelitian Setyowati yang berjudul Hubungan Pengetahuan santriwati Tentang Penyakit Skabies dengan Perilaku Pencegahan Penyakit Skabies di Pondok Pesantren Al Muayyad Tahun 2014, bahwa sebagian besar responden mempunyai perilaku pencegahan baik yaitu sebanyak 44 santriwati $(19,7 \%)$ dan responden yang mempunyai perilaku dalam pencegahan tergolong dalam kategori yang kurang baik sebanyak 167 santriwati $(80,3 \%)$.

\section{Pengetahuan}

Pengetahuan dalam penelitian ini dapat diukur dengan menggunakan alat ukur yaitu kuesioner untuk menjawab semua pertanyaan sebanyak 15 pertanyaan.

Hasil keseluruhan kuesioner di akumulasikan dan di bagikan dengan jumlah responden sehingga di dapatkan nilai rataratanya. Dari hasil penelitian ini menunjukkan bahwa responden yang memiliki pengetahuan kurang sebanyak 46 santri (60,5\%), sedangkan $30(39,5 \%)$ santri lainnya diantaranya memiliki pengetahuan baik tentang perilaku pencegahan skabies. Hasil uji analisis Chi-square diperoleh nilai $\rho$ value $=0,012<\alpha(0,05)$ sehingga dapat disimpulkan yaitu bahwa ada hubungan antara pengetahuan terhadap perilaku pencegahan skabies di pesantren Pancasila Kota Begkulu

. Penelitian ini sesuai dengan penelitian Setyowati tahun 2014 yang berjudul Hubungan Pengetahuan Santriwati Tentang Penyakit Skabies dengan Perilaku Pencegahan Penyakit Skabies di Pondok Pesantren, bahwa sebagian besar responden memiliki pengetahuan yang baik tentang penyakit skabies yaitu sebanyak 44 santriwati $(19,7 \%)$, sedangkan responden yang memiliki pengetahuan kurang baik sebanyak 155 santriwati $(74,5 \%)$.

\section{Peran Tenaga Kesehatan}

Peran tenaga kesehatan dapat diukur dengan menggunakan alat ukur kuesioner yaitu menjawab pertanyaan sebanyak 15 pertanyaan.

Hasil keseluruhan kuesioner di akumulasikan dan dibagikan dengan jumlah responden sehingga didapatkan nilai rata ratanya. Dari hasil penelitian ini menunjukkan bahwa responden yang mengatakan peran tenaga kesehatan kurang berperan sebanyak 33 santri $(76,7 \%)$, sedangkan 21 atau $(63,6 \%)$ santri diantaranya mengatakan bahwa peran tenaga kesehatan memiliki peran yang baik dalam perilaku 
pencegahan skabies. Hasil uji analisis Chisquare diperoleh nilai $\rho$ value $=0,001<\alpha$ $(0,05)$ sehingga dapat disimpulkan bahwa ada hubungan antara peran tenaga kesehatan terhadap perilaku pencegahan skabies di pesantren Pancasila Kota Bengkulu. Dari analisis tersebut dapat disimpulkan bahwa peran tenaga kesehatan yang kurang berperan dapat mempengaruhi perilaku pencegahan skabies para santri yang kurang baik pula.

Penelitian ini sesuai dengan penelitian yang dilakukan Hidayat yang berjudul Faktor - Faktor yang Berhubungan dengan Kebersihan Diri dan Kesehatan Lingkungan di Pesantren Nurul Huda Desa Cibatu Kabupaten Sukabumi Tahun 2011 didapatkan hasil responden yang mengikuti penyuluhan yang dilaksanakan oleh tenaga kesehatan memiliki kecenderungan berperilaku bersih dan sehat, dengan nilai OR sebesar 1,300 berarti bahwa responden yang mengikuti penyuluhan memiliki perilaku hidup bersih dan sehat. Peran adalah tingkah laku seseorang yang diharapkan oleh setiap orang terhadap orang lain disekitarnya. Peran petugas kesehatan adalah sekumpulan tingkah laku dari berbagai petugas kesehatan yang diharapkan oleh masyarakat dalam menjalankan peranannya di tengah - tengah lingkungan masyarakat dalam pengabdiannya kepada masyarakat berkaitan dengan tugas dan tanggung jawabnya sebagai tenaga kesehatan

\section{KESIMPULAN}

Berdasarkan hasil analisa univariat dan pembahasan penelitian yang telah dilakukan oleh peneliti dengan menggunakan pengolahan data komputerisasi tentang suatu hubungan pengetahuan, sumber informasi dan peran tenaga kesehatan terhadap perilaku pencegahan skabies di pesantren Pancasila Kota Bengkulu

Pada penelitian ini didapatkan bahwa berdasarkan distribusi frekuensi terdapat 45 santri $(59,2 \%)$ memiliki perilaku pencegahan skabies yang kurang baik dan 31 santri $(40,8 \%)$ diantaranya yaitu memiliki perilaku pencegahan skabies baik, untuk variabel pengetahuan dalam penelitian didapatkan para santri yang memiliki pengetahuan kurang sebanyak 46 santri $(60,5 \%)$, sedangkan 30 $(39,5 \%)$ santri lainnya, diantaranya memiliki pengetahuan baik tentang perilaku pencegahan skabies.

Variabel sumber informasi sendiri didapatkan hasil bahwa santri yang memiliki sumber informasi kurang sebanyak 42 santri $(55,3 \%)$ dan 23 santri $(67,6 \%)$ diantaranya memiliki sumber informasi baik, sedangkan untuk variabel peran tenaga kesehatan menunjukkan bahwa para santri kelas satu yang mengatakan peran tenaga kesehatan kurang berperan sebanyak 33 santri $(76,7 \%)$, sedangkan sebanyak 21 atau $(63,6 \%)$ santri diantaranya mengatakan bahwa peran tenaga kesehatan memiliki peran yang baik dalam perilaku pencegahan skabies.

Hasil uji statistik didapat nilai $\rho$ value $=$ 0,012 . Hal ini menunjukkan bahwa nilai $\rho<\alpha$ $(0,05)$, sehingga dapat disimpulkan bahwa ada hubungan yang signifikan antara pengetahuan dengan perilaku pencegahan skabies. Dari nilai OR 3,808 dapat simpulkan bahwa responden yang mempunyai pengetahuan baik berpeluang 3,808 atau 4 kali berperilaku baik dalam pencegahan skabies dibandingkan responden dengan pengetahuan yang kurang.

Hasil uji statistik didapat nilai $\rho$ value $=$ 0,000 . Hal ini menunjukkan bahwa nilai $\rho<\alpha$ $(0,05)$, sehingga dapat disimpulkan bahwa ada terdapat hubungan yang signifikan antara sumber informasi dengan perilaku pencegahan skabies. Dari nilai OR 8,886 dapat simpulkan bahwa responden yang mempunyai sumber informasi baik berpeluang 8,886 atau 9 kali untuk berperilaku baik terhadap pencegahan skabies dibandingkan santri dengan sumber informasi yang kurang.

Hasil uji statistik didapat nilai $\rho$ value $=$ 0,001 . Hal ini menunjukkan bahwa nilai $\rho<\alpha$ $(0,05)$, sehingga dapat disimpulkan bahwa terdapat hubungan yang signifikan antara peran tenaga kesehatan dengan perilaku pencegahan skabies. Dari nilai OR 5,775, 
artinya bahwa santri yang mendapatkan peran tenaga kesehatan berpeluang 5,775 atau 6 kali berperilaku baik dalam pencegahan skabies dibandingkan santri yang kurang mendapatkan peran tenaga kesehatan.

\section{SARAN}

Dapat menambah dan memperbaharui informasi kesehatan terutama mengenai pentingnya perilaku hidup bersih dan sehat dengan menjaga kebersihan diri dan lingkungan, melakukan pembinaan secara rutin kepada para santri dalam upaya peningkatan kebersihan diri dan lingkungan pesantren. Khususnya kebersihan diri sendiri seperti mandi $2 \mathrm{x}$ sehari dengan menggunakan sabun mandi, mengganti pakaian jika pakaian sudah lembab atau bercampur keringat, serta tidak menggunakan barang pribadi milik santri lainnya seperti pakaian, handuk dan alat mandi lainnya. Para santri juga sebaiknya menjemur kasur dan mengganti sprei setiap seminggu sekali sehingga dapat mencegah penularan penyakit skabies di lingkungan pesantren dan melakukan kerjasama dengan puskesmas, serta menyediakan tenaga kesehatan di lingkungan pesantren sebagai penanggung jawab unit kesehatan yang telah ada, agar kesehatan para santri selalu terjaga.

Bagi institusi pendidikan diharapkan pembuatan skripsi ini dapat bermanfaat sebagai tambahan bacaan untuk memahami pentingnya kebersihan diri dan lingkungan, sehingga dapat memberikan pengetahuan baru di perpustakaan dan dapat di jadikan wawasan bagi para pembaca atau mahasiswa.

Bagi peneliti selanjutnya, diharapkan meneliti lebih dari satu pondok pesantren sehingga dapat mewakili kejadian skabies di berbagai pondok pesantren guna mengetahui apakah setelah adanya penelitian mengenai perilaku pencegahan skabies ini terdapat perubahan terhadap kejadian skabies di pondok pesantren lainnya, serta diperlukan juga penelitian lebih lanjut terhadap faktor penyebab terjadinya penyakit skabies lainnya, untuk menambahkan dan menyempurnakan penelitian yang sudah ada.

\section{DAFTAR PUSTAKA}

Badri, M. Hygiene Perseorangan Santri Pondok Pesantren Wali Songo Ngabar Ponorogo. Media Penelitian dan Pengembangan Kesehatan. Jurnal. Kesehatan Masyarakat. Vol. 17 No 2. (diakses pada tanggal 7 Mei 2015 pukul 20.00 WIB), diunduh dari Hlm.http://di gilib.litbang.depkes.go.id/go.php? id=jkpbppk gdl-grey- 2008mohbadri2623\&node $=146 \&$ start $=141$; 2008.

Dinas Kesehatan Provinsi Bengkulu. Data Jumlah Penyakit Provinsi Bengkulu. Bengkulu: Profil Bengkulu ; 2018.

Djuanda, A. Ilmu Penyakit Kulit dan Kelamin. Jakarta: Fakultas Kedokteran Universitas Indonesia ; 2010.

Haeri. Faktor-Faktor Yang Berhubungan Dengan Kejadian Skabies Di Pondok Pesantren Darul Huffadh Di Wilayah Puskesmas Kajuara Kab. Bone. Jurnal Kesehatan Masyarakat. Vol. 2 ISSN : 2302-172. (diakses pada tanggal $15 \mathrm{Mei}$ 2015 pukul 19.30WIB), diunduh dari http://library.stikesnh.ac.id/files/disk1/6/ e-library\%20stikes $\% 20$ nani \%20hasanuddin-ummulhaeri-292-126131091-1.pdf ; 2013

Harahap M. Ilmu Penyakit Kulit. Jakarta: Hipokrates ; 2008.

Maharani, A. Penyakit Kulit. Yogyakarta: Pustaka Baru Press ; 2015.

Martano, N. Metode Penelitian Kuantitatif Analisis isi \& Analisis Data Sekunder. Jakarta: Rajagrafindo Persada ; 2010.

Notoatmodjo, S. Promosi kesehatan dan ilmu perilaku. Jakarta: PT. Rineka Cipta ; 2007.

Notoatmodjo, S. Ilmu Kesehatan Lingkungan. Jakarta: PT. Rineka Cipta; 2003.

Notoatmodjo, S. Promosi Kesehatan dan Perilaku Kesehatan. Jakarta: PT. Rineka Cipta ; 2012.

Nursalam. Prosedur Penelitian Suatu Pendekatan Praktik. Jakarta: PT. Rineka Cipta ; 2006.

Ridwan M. Metode dan Tehnik Penyusunan 
Tesis. Bandung: Alpabet; 2002.

Setyowati, D. Hubungan Pengetahuan Santriwati Tentang Penyakit Skabies Dengan Perilaku Pencegahan Penyakit Skabies Di Pondok Pesantren. Skripsi. Surakarta: Sekolah Tinggi Ilmu Kesehatan Aisiyah Surakarta. (diakses pada tanggal 7 Mei 2015 pukul 19.00 WIB), Hidayat, T. Faktor - Faktor Yang Berhubungan Dengan Kebersihan Diri dan Kesehatan Lingkungan Di Pesantren Nurul Huda Desa Cibatu Kab. Sukabumi. Skripsi. Fakultas Kesehatan Masyarakat. Universitas Indonesia. Depok. (diakses pada tanggal 4 Juni 2015 pukul 20.00 WIB), diunduh dari http:/lib.ui.ac.id /file? file=digital $/ 20292769-$ S1405Topik $\%$ 20Hidayat.pdf ; 2011. 